tion of the carbides and the size of their particles influence the rate of attack by acids. The texture of the resisting or 'stainless' steels to steam at high temperatures depends on the distribution of the compounds precipitated from the solid during heating. Oxidising agents produce a thin skin on the surface of many metals, and this protects against further action, or fails to protect, according to the texture of the oxide so formed. On a yet finer scale, certain classes of solids containing 'giant molecules' have their chemical properties determined by the shape of those molecules, whether forming thin sheets, fibres, or a loose network. Examples are graphite and other forms of carbon, textile fibres and the zeolites. The study of texture, usually by means of the microscope but also making use of many physical methods, is therefore an essential part of the study of chemically resistant materials.

\section{The Future of Governments}

An address delivered by N. M. Butler at the Parrish Art Museum, Southampton, Long Island, on September 2, attributes the attack on 'liberalism' in the world generally to the very limited extent to which knowledge and power have been linked in official public life, compared with industrial and commercial life. The wide gap between instructed public opinion and Government, and the control of Government by legal formulæ, by passion and by highly organised and effective self-seeking minorities, are largely responsible for the deadlock which threatens many fields of public action. Mr. Butler does not believe that compulsion, whether by a dictator or by a majority, offers any permanent solution of our difficulties. What is required is intellectual and moral discipline to fit mankind for the use of liberty. Dictatorships, no less than democracies, have failed to readjust their policies or the economic life of the peoples concerned to the revolutionary changes in production and intercourse brought about by the application of science. The highest task of liberalism to-day, he claims, is to meet this situation, to show how to end this international anarchy and confusion and to solve these new problems constructively without resort to any form of compulsion. Mr. Butler outlined very broadly the principles of a programme ensuring not only freedom of thought, speech, worship and assembly but also of opportunity to earn a livelihood, and insisted on the importance of preserving individuality in the economic as in other spheres. The whole area of eivilisation requires widening and integrating to relieve the economic conditions from which the attack on liberalism largely arose, and Government, agriculture, industry, transport, commerce and finance require adjusting to the conditions of human life and action existing to-day.

\section{Industry in New Zealand}

Discussing the prospects of industry in New Zealand in an address to the Dunedin Chamber of Commerce on August 21, Lord Bledisloe said that the decline in international commodity exchange and the growing tendency towards economic selfsufficiency must inevitably cause anxiety in countries like New Zealand, Denmark or Argentina, the economic existence of which is conditional upon the export of agricultural produce. New Zealand will have to search for new directions in which her industrial activities may expand, though this as yet can scarcely be in the direction of large-scale industrial production owing to her small population and limited consumptive capacity. First and foremost, efforts should be made to develop the 'tourist industry', which presents great possibilities provided the travel, hotel and similar interests organise and co-ordinate their efforts. Timber plantations, especially of the native beech, should prove a valuable asset, since conditions elsewhere foreshadow a worldwide timber famine within the next half-century. If properly managed and protected from insect and fungoid pests, the forests should afford remunerative employment to a large section of the rural population. of New Zealand's mineral resources, gold is the most important and indeed seems likely to open up the most promising avenue for providing fresh employment. Yet another development of importance would be the revival of the once profitable kauri-gum industry now made possible by new methods of refining low-grade gum. The extraction of oil from the local 'groper' presents distinct possibilities since it is 100 times richer in vitamin $\mathbf{A}$ than the average cod liver oil. Important new industries might be inaugurated for canning meat and for manufacturing casein from surplus milk; the former could readily be marketed in Britain since there is no quota for canned meat as there is for chilled meat.

\section{Preservation of Natural Woodland}

Mr. W. Dallimore read a paper on amenity planting and the preservation of natural woodlands before Section $K$ at the recent meeting of the British Association at Aberdeen. "Amenity planting," $\mathrm{Mr}$. Dallimore said, "and the preservation of natural woodland may be regarded as common ground whereon arboriculture and sylviculture meet." This somewhat dangerous statement is qualified by the subsequent remark that "In many respects sylviculturists are better placed for general amenity supervision than men who are engaged upon arboriculture". Until comparatively recently, the true work of the sylviculturist was but little understood in Great Britain. In fact, by many it was considered to cover all aspects of the forester's work save that of exploitation and extraction. A truer understanding now exists, and Mr. Dallimore is correct in saying that the sylviculturist generally is in a better position to undertake or supervise general amenity work in woodlands and so forth : though this does not mean that he is always as capable as the arboriculturist specialist. The day has arrived, however, in Great Britain when a sharp division should be made in estates budgets, both Government and privately owned, between all planting done for purely amenity purposes, and plantings undertaken for commercial forestry production. Forestry is a definite business 
concern, and if a profit is to be made, it should not have to carry expenditure incurred for work undertaken to beautify a locality; an object quite apart from the utilisation of the soil as a commercial asset. Mr. Dallimore dealt with the various types of planting for amenity purposes, such as garden and park trees, field and hedgerow trees, road-side trees, small shelter plantations and woods of varying type open to the public as pleasure resorts.

\section{Weather in Great Britain and Ireland in 1933}

THE most recently published annual volume of the Weekly Weather Report (The Weekly Weather Report for the Period February 26, 1933 to March 3, 1934. M.O. 374. London: H.M. Stationery Office. $7 s .6 d$., postage extra) is the fifty-sixth that has appeared since the publication of meteorological data in weeks by the Meteorological Office was first begun, and is the fifth in which the data are largely presented in the form of deviations from normal values of the different elements. The deviations of temperature are given in whole degrees, of accumulated temperature (reckoned from $42^{\circ} \mathrm{F}$., the zero of temperature from the point of view of plant growth) in day degrees, while for rainfall and sunshine the percentage of the normal for the appropriate week or season is quoted. This report is designed to be used for correlation with agricultural data, for which as a time unit the day is regarded as being too short, and the month too long. The year begins and ends, as in former volumes, with early spring, the whole period under review in this case beginning on February 26, 1933, and ending on March 3, 1934, and the tables are based on the records of fiftyseven stations well distributed throughout Great Britain and Ireland. The time of commencement was for England within a wet period following a remarkably dry winter, which came at a favourable time for agriculture in so far as it supplied the land with some reserves of water, and enabled many crops to withstand the drought, heat and abnormal sunshine of the summer and autumn of 1933 far better than they would have done had the winter drought not had this pronounced check. The period as a whole was with few exceptions one with excess of sunshine over England, especially in the south-east and the Midlands. There was general dryness and warmth throughout the British Isles, the warmth being especially pronounced in spring and summer; July and August provided more than one spell of tropical heat, without however quite repeating the very exceptional extremes of the August of the preceding year.

\section{Recent Acquisitions at the Natural History Museum}

Among the recent acquisitions of the Department of Zoology is a collection of 300 birds obtained by Mr. A. W. Vincent in the south-eastern district of the Belgian Congo. This is an area which has been very little investigated from the ornithological point of view. A valuable recent addition to the collection of Hemiptera (bugs) in the Department of Entomology consists of a collection of 17 specimens of
Termitaphidæ presented by Dr. J. G. Myers of the Imperial College of Tropical Agriculture, Trinidad. These rare and little-known insects are found only in the nests of white ants in America and in the Old World, but the nature of this association is not known. A purchase of particular interest is a collection of 500 beetles from Tibet, Central Asia, western China and the Altai Mountains ; the majority of the specimens were described by Continental authors and are paratypes of species hitherto unrepresented in the Department. The Public Schools Exploration Society has presented the whole of the entomological collections made during its recent expedition in Newfoundland. The Department of Geology has acquired a collection of primitive fish-like Ostracoderms comprising a hundred specimens obtained by Mr. Wickham King, chiefly from the Old Red Sandstone of Worcestershire; and a fine series collected by Dr. E. I. White and Mr. H. A. Toombs from Herefordshire, comprising many forms new to science, of which the most interesting are specimens of Pteraspis, which show for the first time the unusual form of the tail. A valuable collection of gemstones has been bequeathed to the Department of Minerals by the late Mr. T. B. Clarke-Thornhill, including ninety cut stones, many of them of large size, of various minerals-a fine series of sixteen coloured diamonds, parti-coloured corundum, tourmaline, opal, alexandrite, phenakite, etc.; also uncut specimens of opal, moonstone, and large masses of Kauri-gum from New Zealand. The first meteorite to be recorded from Rhodesia, a stone weighing $48 \mathrm{lb} .11 \mathrm{oz}$. which fell on March 7, 1934, in the Mangwendi native reserve, $\mathbf{4 0}$ miles east of Salisbury, has been presented by the Government of Southern Rhodesia.

\section{Proposed Museum at Verulamium}

The City Council of St. Albans is preparing plans and proposes to seek powers for raising $£ 15,000$ for the erection of a museum on the site of the RomanoBritish city of Verulamium. The museum will be devoted to housing the valuable collection of antiquities found on the site during its recent excavation by Dr. and Mrs. Mortimer Wheeler. The proposal of the Council is a fitting sequel to its enlightened action whereby the excavation, which has proved so fruitful in results, was made possible. Not only has the importance of Verulamium as a centre of RomanoBritish life and culture been fully confirmed by increased knowledge, but also it is now possible to appreciate more justly the significance and influence of this centre in relation to the rest of the peoples of pre-Roman Britain. The value of the collections to the student will be vastly enhanced by the opportunity the building will afford for the proper display of these antiquities without the distraction of other exhibits by their side; while the effect of such a display as a unitary collection in the midst of its native setting will be to enhance both its historical and its cultural value. The Council is wisely consulting Dr. Mortimer Wheeler before deciding on the exact site of the museum in order to avoid the possibility of interference with any future exploration. 